\title{
Update in small bowel physiology: Part 2
}

RJ FINGEROTE, MD, FRCPC, S CHURNRATANAKUL, MD, M KEELAN, MSC, K MAdSEN, PHD, ABR ThOMSON, MD, PHD, FRCPC, FACP

ABSTRACT: The recent advances in clinically important diseases of the small intestine have been reviewed; however, the basis for many of these clinical advances rests with important observations on alterations in the physiology of the small intestine, as well as mechanistic observations of alterations in small intestinal function in models of human disease. In this review a summary of the past year's literature is presented which will draw attention to the considerable progress in small bowel physiology which will soon be translated into an improved understanding of the pathophysiology of a variety of intestinal disorders. Can J Gastroenterol 1990;4(8):503-516

Key Words: Intestinal adaptation, Intestinal electrolyte transport, Intestinal motility, Radiation enteritis, Small bowel physiology

\section{Derniers développements dans la physiologie du grêle: Deuxième partie}

RESUME: Le présent article procède à la revue des progrès récemment réalisés dans les maladies du grêle qui sont d'intérêt clinique; néanmoins, nombre de ces progrès cliniques sont fondés sur des observations importantes des altérations de la physiologie du grêle, ainsi que sur des observations mécaniques des altérations fonctionnelles du grêle dans des modèles expérimentaux de maladies humaines. Les auteurs proposent un sommaire de la littérature de l'année précédente, soulignant ainsi l'ampleur considérable des progrès réal isés dans la physiologie de lintestin grêle, lesquels se traduiront bientôt par une meilleure compréhension de la physiopathologie d'une variété d'affections intestinales.

Division of Gastroenterology, Department of Medicine, University of Alberta, Edmonton, Alberta

Correspondence and reprints: Dr ABR Thomson, 519 Robert Newton Research Building, University of Alberta, Edmonton, Alberta T6G $2 \mathrm{C} 2$

Received for publication February 6, 1990. Accepted June 20, 1990
$\mathrm{T}$ HE RECENT ADVANCES IN CLINIcally important diseases of the small intestine have been reviewed (1); however, the basis for many of these clinical advances rests with important observations on alterations in the physiology of the small intestine, as well as mechanistic observations of alterations in small intestinal function in models of human disease. In this review a summary of the past year's literature is presented which will draw attention to the considerable progress in small bowel physiology which will soon be translated into an improved understanding of the pathophysiology of a variety of intestinal disorders.

\section{SALT AND WATER}

Intestinal electrolyte transport and diarrheal disease have been reviewed (2). Sodium absorption has been extensively studied in vitro in the rabbit ileum for which three major mechanisms have been described. Approximately $50 \%$ of ileal sodium absorption occurs via nutrient-coupled electrogenic absorption or electroneutral sodium-chloride cotransport. 


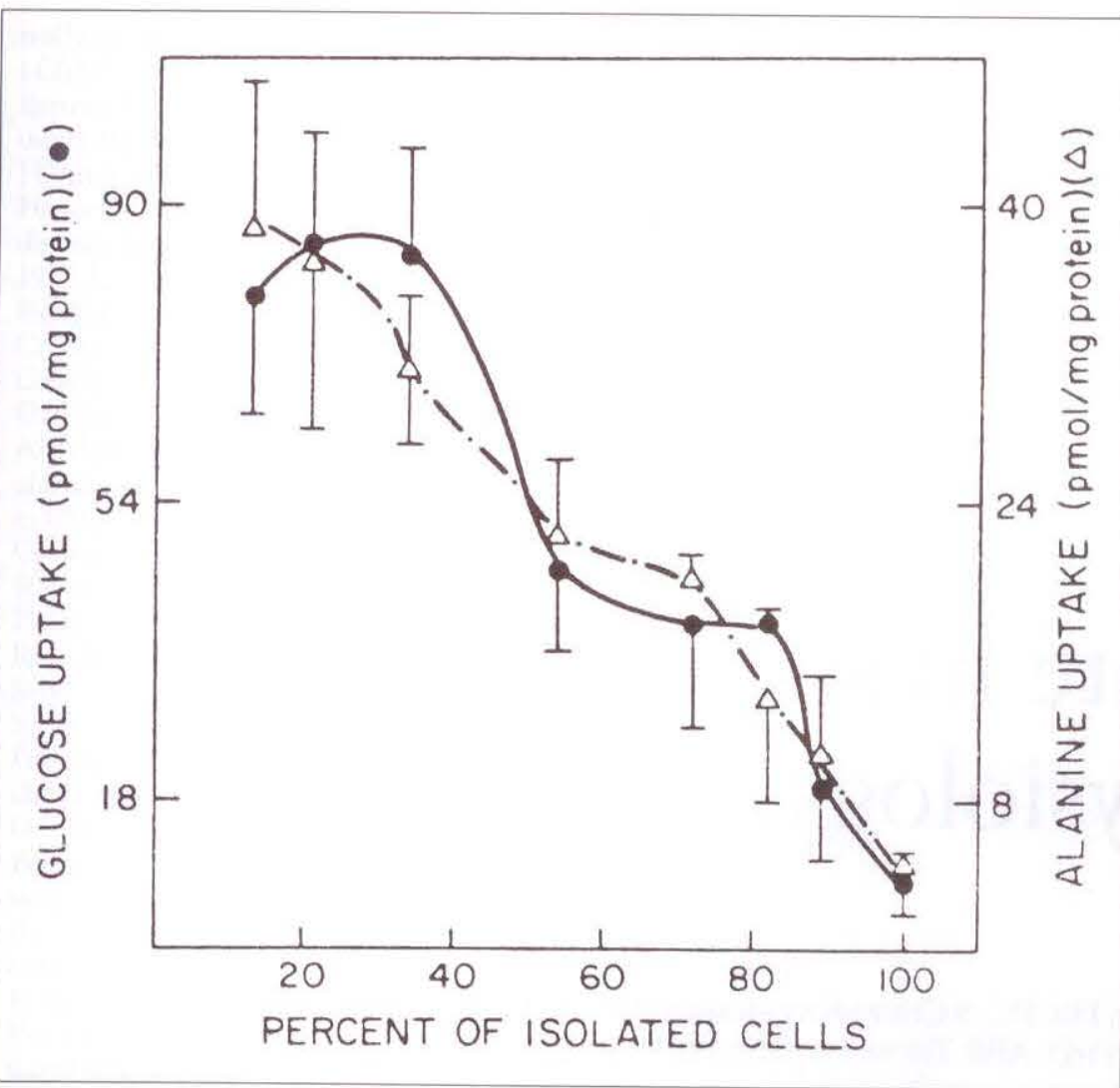

Figure 1) Sodium-stimulated uptake of glucose or alanine in brush border membrane vesicles isolated from cells along the crypt-villus axis. Brush border membranes were prepared by the cation precipitation method from each of eight cell fractions collected sequentially along the crypt-villus axis. (Reprinted with permission from Meddings JB, Thiesen S. Am J Physiol 1989;256:G931-40)

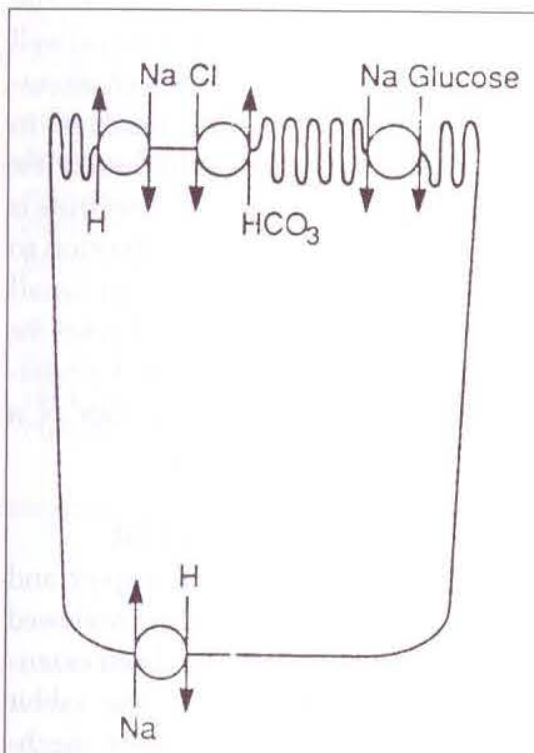

VILLUS

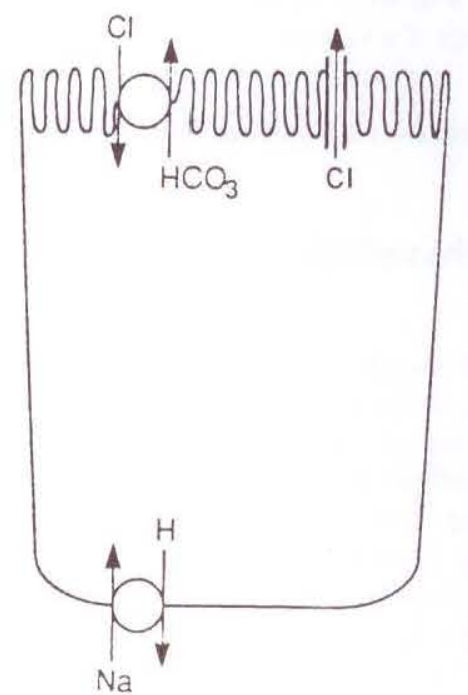

CRYPT
Figure 2) Transport pathways demonstrated in the study by Knicklebein. (Reprinted with permission from Knickelbein RG, Aronson PS, Dobbins JW. J Clin Invest 1988;82:2158-63)
Electroneutral transport is maintained by two parallel antiport systems of sodium/hydrogen and chloride/bicarbonate exchange. At least $50 \%$ of sodium absorption occurs via nutrientindependent electrogenic absorption, which is not inhibited by amiloride but is inhibited by the amiloride analogue phenamil (3). This suggests that sodium absorption in the rabbit ileum may occur via sodium channels in which the amiloride-binding site has been sig. nificantly altered.

Villus-crypt axis: Indirect evidence suggests that villus cells are the sites of absorption of nutrients and electrolytes while crypt cells are the sites of secretion. The sodium/hydrogen and chloride/bicarbonate exchanges occur on the ileal brush border membrane (BBM) and probably account for the coupling of sodium and chloride ab. sorption. In villus cells, sodium /hydrogen exchange activity has been described on both the BBM and basolateral membrane (BLM), whereas in the crypt cells, sodium/hydrogen exchange activity is found only on the BLM. In contrast, chloride/bicarbonate exchange activity is found only on the BBM in both villus and crypt cells (4). $B B M$ vesicle studies demonstrate that sodium-stimulated alanine and glucose uptake is higher in upper villus versus crypt cells (Figure 1). In contrast, chloride/bicarbonate exchange is relatively constant, suggesting that this exchanger is on the BBM of both villus and crypt cells.

BBM sodium/hydrogen exchange, like glucose and alanine uptake, is less in cells harvested from the crypt and lower villus; sodium/hydrogen exchange activity is only present in BBM from villus cells. These results are summarized schematically in Figure 2.

$\mathrm{Na}^{+}, \mathrm{K}^{+}$-ATPase is an intrinsic plasma membrane protein that catalyzes the transport of sodium out of and potassium into cells. In addition to this enzyme, $\mathrm{Na}^{+}$-ATPase activity has been demonstrated in the BLM of guinea pig and rat jejunum (5). $\mathrm{Na}^{+}$-ATPase is present in lesser quantities than $\mathrm{Na}^{+}, \mathrm{K}^{+}$-ATPase, is unaffected by ouabain and is inhibited partially by furosemide and totally by ethacrynate. 
It is present in the intestinal mucosa of normal and diabetic rats. The importance of these enzymes in fluid absorption and secretion remains to be established.

Arterial pH: Arterial $\mathrm{pH}$ affects sodium chloride absorption, while arterial bicarbonate concentration affects chloride/bicarbonate exchange. When the systemic $\mathrm{pH}$ is reduced by either respiratory or metabolic means in an anesthetized animal, water and sodium chloride absorption increase. Increased arterial bicarbonate concentration independently increases chloride absorption and bicarbonate secretion. This increased water and electrolyte absorption occurring in systemic acidosis could possibly prevent or reverse cholera toxin-induced ileal secretion in vivo. Furthermore, decreases in arterial $\mathrm{pH}$ increase absorption in control loops of rabbit intestine, as well as in adjacent loops perfused with a Ringer's solution containing heat-stable enterotoxin (cyclic guanosine monophosphatemediated secretion), or hypertonic mannitol (passive osmotically mediared secretion) or glucose (6).

Escherichia coli gastroenteritis: E coli produces gastroenteritis by at least five different pathogenic mechanisms. In a model using rabbit intestinal mucosa explants (7), enteropathogenic E coli 0111 initially attached to the ileal mucosa through goblet cells and the mucus layer covering the villi. This was followed by binding to the bases of the microvilli, which then became elongated, vesiculated and effaced. Enteropathogenic E coli 0111 were also capable of producing effacement of gastric, duodenal, jejunal and colonic mucosa. E coli which produce heatstable enterotoxin caused intestinal fluid secretion, with the degree to which heat-stable enterotoxin was inactivated or removed from the intestine correlating with the diarrheal response. Cholera: The profuse diarrhea observed in cholera is caused by Vibrio cholerae enterotoxin. Cholera toxin activates adenylate cyclase, thereby increasing the cyclic adenosine 3',5'-monophosphate (cAMP) concentration in the intestinal mucosa. Cyclic AMP is formed by adenylate cyclase and degraded by phosphodiesterases. The fluid transport response to cholera toxin and the specific activities of adenylate cyclase and phosphodiesterase decline progressively from jejunum to colon, yet cAMP concentrations are lowest in the jejunum and highest in the colon (8). Since cAMP concentrations in the total mucosal homogenate do not parallel cholera toxin-induced fluid secretion, the activities of adenylate cyclase and phosphodiesterase suggest a relationship between fluid secretion and turnover rather than content of cAMP.

In addition, 5-hydroxytryptamine and prostaglandin $\mathrm{E}_{2}$ may be involved in the pathogenesis of cholera. Cholera toxin causes luminal release of 5 . hydroxytryptamine and prostaglandin $E_{2}$ (9). The dose-response curve for cholera toxin-induced fluid secretion is shifted to the right by indomethacin and ketanserin. Neither agent causes a change in cholera toxin-induced release of 5-hydroxytryptamine, but both agents decrease the release of prostaglandin $E_{2}$. Although indomethacin and ketanserin reduced levels of prostaglandin $\mathrm{E}_{2}$, they did not alter mucosal cAMP levels in response to cholera toxin. This suggests that endogenous prostaglandins may not be involved in cholera-induced secretion. The calcium channel blockers verapamil and nifedipine dose-dependently reduce cholera toxin-induced fluid secretion without affecting the release of 5-hydroxytryptamine, prostaglandin $\mathrm{E}_{2}$ or cAMP. Cholera toxin-induced fluid secretion in vivo may be caused at least in part by the release of 5-hydroxytryptamine, which in turn stimulates the formation of prostaglandin $\mathrm{E}_{2}$ and therefore cAMP. In human jejunum, 5-hydroxytryptamine reverses normal fluid and electrolyte absorption, causing profuse secretion. This effect of 5-hydroxytryptamine is partially blocked by indomethacin, providing further evidence in favour of the theory that prostaglandins are involved in 5-hydroxytryptamine-induced intestinal fluid secretion (10).

Signals: Kinins are endogenously formed peptides that have diverse biological actions. Low (subnanomolar or nanomolar) concentrations of kinins cause intestinal smooth muscle contraction and evoke mucosal electrolyte secretion. The importance of kinins and prostaglandins in the intestine have been reviewed $(11,12)$. Bradykinin and kallidin are the predominant kinins that affect the gastrointestinal tract, stimulating phospholipases $\mathrm{A}_{2}$ and $C$. Two subgroups of kinin receptors have been identified and the $B_{2}$ type receptor appears to be responsible for both contraction and secretion.

Free cytosolic calcium is involved in the regulation of active intestinal sodium and chloride transport in the rabbit ileum. In most cells, calcium concentration in the cytoplasm is determined by calcium entry or extrusion and the action of mitochondria and the endoplasmic reticulum in releasing or sequestering calcium from the cytoplasm. In many cells calcium channels are important for regulating calcium entry. There are three major types of calcium antagonists or entry blocking drugs: phenylalkylamines, eg, verapamil and (1)-desmethoxyverapamil (D888); dihydropyridines, eg, nitrendipine and nifedipine; and benzothiazepines, eg, diltiazem. Calcium channels have been demonstrated in the BLM of rabbit ileal epithelium, responsive to all three major types of drugs (13). These transport and hinding studies suggest that two types of calcium channels are present in ileal epithelial cells, one of which interacts with dihydropyridines, phenylalkylamines and benzothiazepines at three different sites, and the other which only interacts with phenylalkylamines. The effect of calcium channel blockers on nutrient absorption needs to be established.

Intestinal adenylate cyclase activity may be partially calcium/calmodulindependent: cAMP may directly increase cytosolic calcium by releasing it from endogenous stores. Selective inhibitors of calmodulin may have potential clinical use as antidiarrheal agents. Previous studies have shown that compounds (such as chlorpromazine and trifluoperazine) that bind calmodulin inhibit intestinal secretion stimulated by agents that elevate intracellular free calcium. CGS 9343B is a potent and 
specific inhibitor of calmodulin but not of protein kinase C. It inhibits the intestinal secretion stimulated by cholera toxin as well as cholera toxin-induced increases in mucosal cAMP (14). The synthetic antidiarrheal drug loperamide binds calmodulin, thereby inhibiting its activity. The stimulatory effect of loperamide on the $\mathrm{Cl}^{-} / \mathrm{OH}^{-}$antiport, and coupled sodium chloride transport by BBM vesicles of human ileum is mediated by inhibition of calmodulin activity (15).

Enteric nervous system: The enteric nervous system plays a key role in the maintenance of body fluid homeostasis by regulating the transport of ions by the intestinal epithelium $(16,17)$.

The topic of receptor regulation of ion transport in the intestinal epithelium has been reviewed (18). Muscarinic receptors in the gastrointestinal tract are present on enteric neurons, presynaptic and prejunctional axonal endings, intramural endocrine cells and effector cells such as smooth muscle, glandular and epithelial cells (19).

Tonically active submucosal neurons continuously suppress ion transport and limit the absorptive capacity of the intestine (20); ion transport is altered when neurotransmitters released from motor neurons interact with receptors on epithelial cells to initiate stimulusresponse coupling. Adrenergic fibres of the enteric nervous system enter the intestinal wall in the mesenteric nerves, are prevalent around the epithelial crypts and ramify among neurons of the submucous plexus, where norepinephrine coexists with somatostatin. The nonadrenergic fibres that supply the blood vessels are present with neuropeptide $\mathrm{Y}$ and somatostatin. Neuropeptide $Y$ and norepinephrine enhance absorption of ions and water by acting directly on the epithelium. Norepinephrine also increases absorption by acting on nerves and enterocytes. Peptide histidine isoleucine as well as vasoactive intestinal peptide and histamine also directly affect enterocytes (21).

While ion transport in the suckling mouse jejunum is regulated by the enteric nervous system, sugar transport does not appear to be influenced by muscarinic cholinergic agonists (22). The two enkephalin peptides Met ${ }^{5}$ enkephalin and Leu ${ }^{5}$-enkephalin are present in the gastrointestinal tract of humans. The intramural distribution of the pro-enkephalin A-derived peptides in the human gut has been described (23). 5-Hydroxytryptamine1 receptors are located on the cell bodies of myenteric but not submucosal neurons of guinea pig intestine (24). Apart from acetylcholine, the signals that transduce changes in epithelial ion transport are unknown. However, numerous peptides are under study as potential mediators of fluid and electrolyte transport. Intravenous infusions of low doses of vasoactive intestinal polypeptide, peptide histidine valine -42 , and peptide histidine methionine (the rat equivalent of peptide histidine isoleucine) into anesthetized rats reduce fluid absorption and increase secretion in the intestine (25). Peptides: Vasoactive intestinal peptide is a neurotransmitter found in abundance in the submucosal neurons of the enteric nervous system. It interacts with its receptors on enterocyte membranes, stimulating the production of $\mathrm{CAMP}$ in the cells. It also reduces enterocyte glucose oxidation and enhances palmitate oxidation (26). In patients with Verner-Morrison syndrome, watery diarrhea is associated with raised plasma levels of vasoactive intestinal peptide, peptide histidine valine- 42 and peptide histidine methionine; the latter two may be as important as vasoactive intestinal peptide in causing fluid secretion.

Gastrin-releasing peptide is associated with intrinsic neurons in the intestinal tract of man. It reduces intestinal salt and water absorption and stimulates chloride secretion through interactions with gastrin-releasing peptide receptors located in the intestinal mucosa and submucosa (27). Immunoreactive calcitonin gene-related peptide is present in nerves throughout the rat gastrointestinal tract. Calcitonin gene-related peptide increases mesenteric bloodflow, inhibits acid secretion, stimulates gastrointestinal somatostatin release, and causes an im- mediate dose-dependent secretion of water in the large but not small intes tine of the rat (28). Elevated concentrations of calcitonin gene-related peptide have been reported in patients with medullary thyroid carcinoma and may contribute to their severe watery diarrhea.

Atrial natriuretic factor stimulates guanosine $3^{\prime}, 5^{\prime}$-cyclic monophosphate production in the rat small intestine and inhibits absorption and stimulates secretion of water in the small intestine. Atrial natriuretic factor has been detected by radioimmunoassay in the guinea pig intestine (29), and atrial natriuretic factor binding sites have been identified in the rat jejunum (30).

Octreotide (SMS 201-995) is a longacting and potent analogue of somatostatin which can be administered subcutaneously. There are in vitro differences between the effects of SMS 201-995 and native somatostatin (31). However, the relative lack of toxicity and the unique biological actions of this compound are of potential clinical in. terest for the treatment of diarrheal diseases. Octreotide delays transit and increases water, sodium and calorie ab. sorption from meals in patients with short bowel syndrome (32), and its therapeutic potential in this condition needs to be explored further.

Compounds that stimulate mucosal alpha-adrenergic receptors enhance intestinal absorption of sodium and in. hibit secretion of bicarbonate and chloride ions. These effects are mediated by stimulation of specific alpha-2 adrenoceptors on enterocytes. Clonidine hydrochloride is a selective alpha-2 receptor agonist which inhibits intestinal secretion in animals induced by cholera toxin, prostaglandins and 5 . hydroxytryptamine. In man, clonidine causes a modest reduction of fecal electrolyte losses but does not sig. nificantly reduce fecal fluid loss in patients with cholera (33). Clonidine also prolongs intestinal transit time (34).

Oral rehydration solution: Patients with secretory diarrhea retain the ability to absorb water and sodium in the presence of glucose. This observa tion has provided a scientific rationale 
for rehydrating such patients with oral rehydration (glucose-electrolyte) solution. The importance of including bicarbonate, citrate and acetate in oral rehydration solution is uncertain (35). While these three anions stimulate water and sodium absorption from the normal human jejunum, their specific effects in acute diarrheal states are unknown. Bicarbonate- and chloridecontaining glucose or glycine electrolyte solutions induce a significantly greater absorption of sodium, potassium and water in rat intestine compared with those containing chloride only (36). In cholera toxintreated small intestine, none of these anions affected water and sodium secretion in the ileum; in fact, in the jejunum acetate and citrate actually enhanced the secretory state for both water and sodium (37). Bicarbonate-free and bicarbonate-containing oral rehydration solution may be equally effective in correcting dehydration. A further study has even suggested that stool output may be greater in patients treated with a bicarbonate-containing oral rehydration solution (38). This raises the possibility that including bicarbonate, acetate or citrate in oral rehydration solution may not promote water and sodium absorption in the secreting intestine during acute diarrheal diseases.

\section{INTESTINAL ADAPTATION}

Small intestinal pacing enhances absorption from the canine small bowel and may be of benefit for motility disorders associated with decreased transit time (39). After jejunal and ileal resection in rats, postprandial motor activity in the small bowel is enhanced (40). This emphasizes the role of intestinal motility in the process of adaptation.

Glutamine: The intestine prefers the amino acid glutamine as its major fuel source. Glutaminase is the entry enzyme for oxidation of glutamine. The activity of glutaminase is greater in cells isolated from the villus-crypt junction than in cells isolated from either villus or crypt compartments (41). Although substantial amounts of glutamine are taken up by mucosal cells, most appears to be metabolized to pyruvate. Up to 20 to $30 \%$ of plasma glutamine is extracted with each circulation through the mesenteric system for use by the enterocytes and colonocytes. Current parenteral nutrition solutions do not contain glutamine or glutamate. When glutamine-containing total parenteral nutrition (TPN) solution is given to rats, the intestinal nitrogen content of the stomach and colon is preserved as opposed to when standard TPN is given, and the nitrogen content of small bowel is greater than that of chow-fed animals (42). Adding glutamine increases maltase activity in the small bowel and protects the liver from fatty infiltration.

Short chain fatty acids: Short chain fatty acids (acetate, propionate and butyrate) are normally produced by bacterial fermentation of dietary carbohydrates and fibre polysaccharides in the colon and absorbed by colonic mucosa. Intraluminal as well as intraperitoneal injections of short chain fatty acids stimulate mucosal proliferation in the jejunum and ileum of normal rats. The addition of short chain fatty acids to TPN following small bowel resection in adult rats prevents the resection- and TPN-associated loss of jejunal mucosal weight, DNA, RNA, protein, ileal mucosal weight and sodium content (43). The time is ripe to explore the possible benefits of glutamine and short chain fatty acids in TPN solutions for humans.

Focal epithelial discontinuities of the small intestine may be rapidly resealed. Such reparative processes may substantially limit the deleterious physiological impact of superficial intestinal injury (44). Neither continuous contact between migrating cells and BLM, nor complete covering of secreted mucus appears necessary for epithelial restitution to occur (45).

Permeability: The mechanisms responsible for increased intestinal permeability in disorders such as Crohn's disease, celiac sprue, rheumatoid arthritis and indomethacin-associated enteritis are not well understood. Polyethylene glycol 900 may be a suitable probe molecule for studying intestinal permeability changes (46), with most of the polyethylene glycol 900 transport occurring through paracellular tight junctions. After extensive $(80 \%)$ distal small bowel resection in rats, mucosal permeability of the remaining small and large intestine increased (47). The importance of tight junctions has been reviewed (48). Cytokine interferon derived from lymphoid cells diminishes monolayer resistance of the $\mathrm{T}_{84}$ human intestinal epithelial cell line (49). This is due to an effect of cytokine interferon on tight junction permeability. Therefore, it has been speculated that, in disease states, products of activation of lymphoid cells might influence barrier function of intestinal and perhaps other epithelia.

\section{EPITHELIAL CELL PROLIFERATION}

Ornithine decarboxylase: The topic of gastrointestinal epithelial cell proliferation and differentiation has been reviewed $(50,51)$. Ornithine decarboxylase is the initial rate-limiting enzyme in polyamine synthesis. Increased ornithine decarboxylase activity is one of the earliest biochemical events associated with cellular proliferation. Refeeding fasted rats is a potent stimulus for mucosal growth associated with an increase in ornithine decarboxylase in both small and large intestinal mucosa. In the small bowel almost all of this increase occurs in mature villus rather than in proliferative crypt cells. Inhibiting ornithine decarboxylase with difluoromethylornithine blocks the growth response. With a highly specific polyclonal antiserum to ornithine decarboxylase, it was shown that in the fasted rat ornithine decarboxylase is localized almost exclusively to the villus cells (52). With refeeding, the amount of immunoreactive ornithine decarboxylase increases in both villus and crypt cells. Epidermal growth factor, like gastrin, increased ornithine decarboxylase in both crypt and villus cells, whereas in situ infusion of glycine increased ornithine decarboxylase in villus cells only. Thus, luminal nutrients increase enzyme levels in the absorptive villus cells, while trophic peptides stimulate ornithine decarboxylase synthesis in the proliferative crypt cells as well.

The stromal-epithelial interaction is 
a potent driving force in the development of the intestinal mucosa, and ensures tissue-specific cellular differentiation. Fetal rat intestinal epithelium cell colonies explanted in vitro on the 15 th day of gestation failed to differentiate in plain monoculture. When cocultured with either gastric, fetal skin or intestinal mesenchyme, cellular proliferation was increased. In co-culture with intestinal mesenchyme, definite signs of differentiation occurred within three to six days of culture. Cells became polarized and covered with a regular brush border and developed brush border enzymes. This suggests that differentiation of endodermal cells is induced by organotypic mesenchymal cells in vitro (53).

Polyamines: Polyamines (putrescine, spermidine and spermine) are polycations present in food and produced by gastrointestinal tract flora. Polyamines may also be synthesized in the body, with tissue concentrations regulated by the enzymes ornithine decarboxylase, spermine-spermidine $\mathrm{N}$-acetyl transferase and s-adenosylmethionine decarboxylase. Alternatively, polyamines may be transported into the cell from the extracellular medium: spermidine uptake depends on sodium cotransport and possibly also on a process which is energy-dependent, saturable, ouabaininsensitive and dependent on the electrical gradient established by the $\mathrm{Na}^{+}, \mathrm{K}^{+}$-ATPase (54).

Polyamines are involved in growth and differentiation and are found in high concentrations in cells. Polyamine synthesis usually precedes that of DNA. Depletion of polyamines attenuates trophic responses in a number of tissues. Likewise, physiological concentrations of polyamines may be involved in the regulation of protein synthesis. Putrescine is a stimulant to epithelial, DNA, RNA and protein syntheses in cultured fetal rat small intestine (55).

Polyamines are essential for normal proliferation of cultured gastrointestinal crypt epithelial cells (56), and polyamine biosynthesis is regulated by a calcium-activated calmodulin-dependent process.

Putrescine is a biogenic amine which is a favoured substrate of the enzyme diamine oxidase. The histaminediamine oxidase system is involved in mucosal proliferation. Diamine oxidase activity increased following $70 \%$ resection of the small intestine in the rat. However, administration of a specific inhibitor of diamine oxidase was without influence on mucosal proliferation (57). This raises the question of the relevance of diamine oxidase in mucosal proliferation.

Polyamine levels, especially putrescine, fall after a single whole body dose of $3 \mathrm{~Gy}$ irradiation. Therefore, measurement of polyamine content may be useful in monitoring the damage and recovery phases of radiation injury in the small intestine (58). Inhibition of ornithine decarboxylase activity by difluoromethylornithine attenuates prostaglandin-mediated trophic effects on the rat duodenum (59), suggesting that polyamines are required for the prostaglandin-stimulated growth of rat duodenal mucosa.

The distal bowel of the neonatal piglet has a low capacity for generating oxidants via xanthine oxidase. As well, the neonatal piglet ileum has higher superoxide dismutase activity and lower glutathione peroxidase activity than is found in older animals (60). Neonatal piglet intestine may therefore have a lower capacity to detoxify hydrogen peroxide than the intestine of older animals. The importance of these observations to the development of necrotizing enterocolitis is unclear.

\section{EPIDERMAL GROWTH FACTOR}

Epidermal growth factor, a polypeptide hormone of 53 amino acid residues, stimulates cell division in the gastrointestinal tract. It is present in human submandibular glands, stomach, duodenum, pancreas, saliva, and gastric and pancreatic juice. Milk contains a large amount of epidermal growth factor, and appears to be an important source in the suckling period (61). In man, epidermal growth factor also plays an important role in the development of the human fetal gastrointestinal tract (62), although it has been questioned whether this is a physiological or pharmacological effect (63). Epidermal growth factor (beta-urogastrone) has no protective activity in the indo. methacin-induced intestinal lesion model, although it does reduce the necrotizing action of ethanol on the gastric mucosa (64). Epidermal growth factor and glucocorticoids have been reported to promote the growth and maturation of digestive tissues in developing animals. As well, bombesin, given either orally or subcutaneously, has been reported to promote growth in the digestive tract of the neonatal rat (65).

Epidermal growth factor stimulates proliferation and maturation of the preand postnatal intestine. Human epidermal growth factor or urogastrone is a potent stimulator of adult intestinal epithelial cell proliferation in rats and humans. Epidermal growth factor can induce ornithine decarboxylase synthesis. Urogastrone-induced intestinal cell proliferation is blocked by difluoromethylornithine, suggesting that or nithine decarboxylase is essential for effecting the proliferative response of the stomach and small intestine to urogastrone (66). When biosynthetic recombinant urogastrone was ad. ministered to two infants with congenital microvillous atrophy, increases in the crypt mitotic index and intestinal disaccharidase activity were documented. However, no clinical improvement resulted, and both patients died of TPN catheter-related sepsis (67).

Transforming growth factor: Transforming growth factors alpha and beta modulate the proliferation and dif. ferentiation of the intestinal epi. thelium. Receptors have been identified in isolated primary rat intes. tinal epithelial cells and in rat intestinal crypt cell-derived cell line (68). No epidermal growth factor transcripts were detected, suggesting that the true ligand of the epidermal growth factor receptor was transforming growth factor alpha. Production of transforming growth factor alpha was greatest in differentiated cells, whereas the growth. inhibiting transforming growth factor beta was predominantly found in undifferentiated mitotically active crypt cells. This suggests that the balance of crypt cell proliferative activity with vil. 


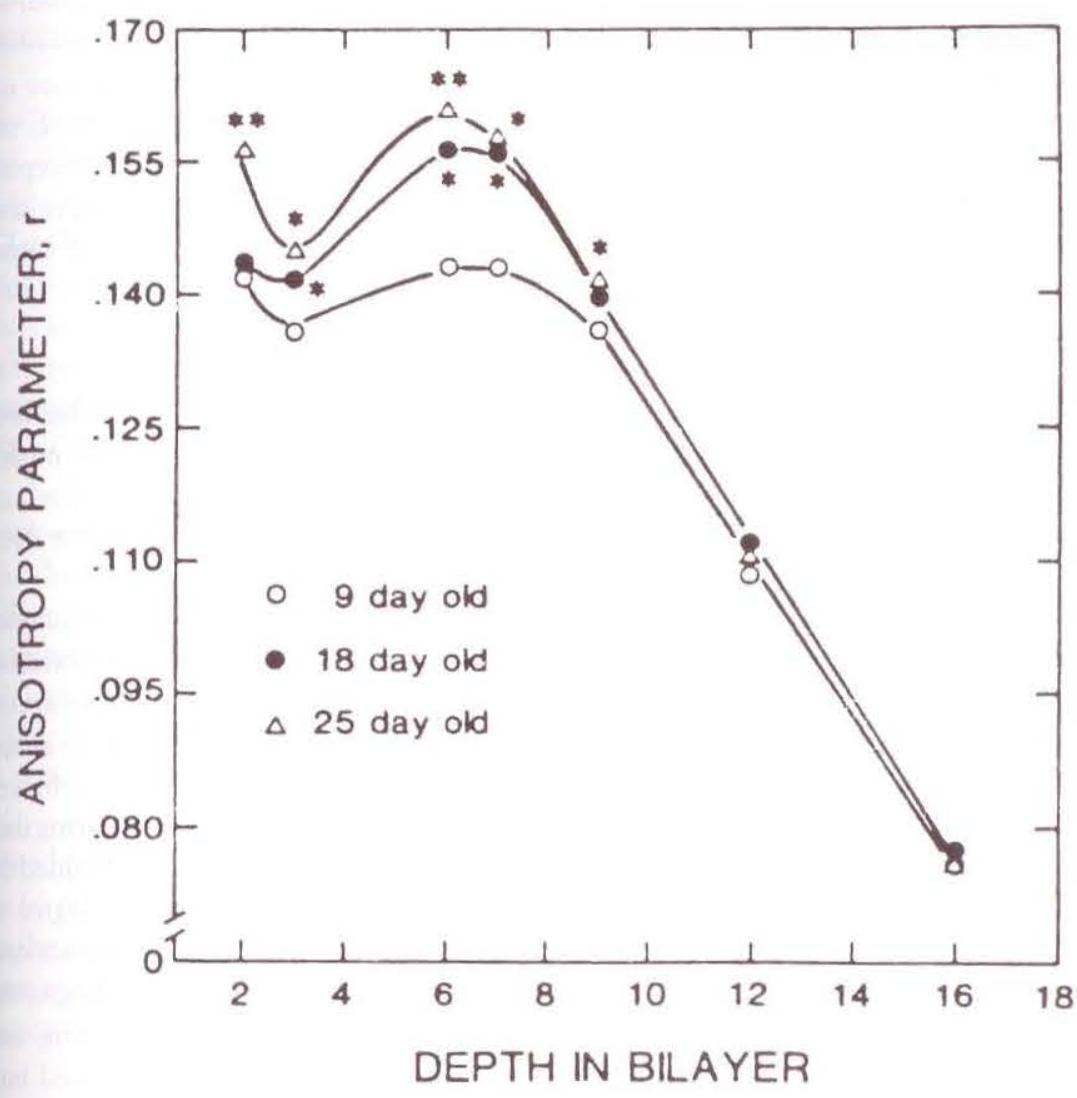

Figure 3) Dynamic component of membrane fluidity. Data represent mean anisotropy parameters obtained on at least four occasions in each of four membrane preparations. Standard error for each point was smaller than the size of the symbol. The horizontal axis represents carbon of either stearic or palmitic acid. *Significant difference from nine-day-old animals; **Significant difference from both nine-and 18-day-old animals. (Reprinted with permission from Knicklebein RG, Aronson PS, Dobbins JW. J Clin Invest 1988;82:2158-63)

lus cell maturation and senescence may be controlled by a paradoxical feedback mechanism in which crypt cells produce transforming growth factor beta, thereby putting a 'brake' on their own proliferation. This may then be counterbalanced by villus cell production of transforming growth factor alpha.

Protein kinase C: The unsaturated fatty acids arachidonic, linoleic and deic acids induce the translocation of protein kinase $\mathrm{C}$ activity from the soluble to the membrane fraction of colonic mucosa. This effect can be suppressed by an inhibitor of protein kinase Cactivity (69). Unsaturated fatty acids also increase the breakdown of poly. phosphoinositides when added to isolated colonic epithelium.

Feeding difluoromethylornithine to weanling rats causes diarrhea and damage to the small intestine, presumably due to reduced cell division in the proliferative compartment of the crypt regions. While malnutrition may alter intestinal DNA, protein and BBM enzymes, malnutrition in the immediate postnatal period does not increase the sensitivity of the small intestine to the damaging effect of difluoromethylornithine (70).

\section{AGEING}

Sucrase: Jejunal BBM sucrase activity, which falls with fasting or a low carbohydrate diet, is rapidly restored by a high carbohydrate diet. High carbohydrate diets or glucose refeeding increases synthesis rates and concentrations of BBM sucrase-isomaltase (71). These concentration increases of both sucrase-isomaltase and maltaseglucoamylase occur along the length of the villus column, where luminal glucose perfusion rapidly stimulates mucosal protein synthesis (72). This effect is due to a direct alteration of mucosal metabolism rather than to indirect systemic effects. Stimulation of the rate of synthesis of mucosal protein by luminal glucose depends, therefore, on mucosal metabolism of the carbohydrate. Stimulation of mucosal protein synthesis probably also explains why luminal glucose perfusion causes a rapid increase in the uptake of arterial amino acids by canine small intestine.

Intestinal sucrase is a nutritionally important enzyme for the hydrolysis of sucrose into glucose and fructose. This enzyme is synthesized intracellularly as a pro-sucrase-isomaltase precursor, is transported to the BBM of the absorptive cell and is cleaved by pancreatic proteases to become a noncovalently bound sucrase-isomaltase complex. In the rat, jejunal sucrase activity is not detected until 16 to 18 days after birth. Thereafter, activity rises to adult levels. Immunoreactive sucrase-isomaltase and sucrase activity are present over the entire jejunal mucosa by day 22 , increase progressively until day 32 , and are sequentially modulated by thyroid and adrenocortical hormones (73). Both normal and precocious development of sucrase activity and its distribution along the length of the small intestine is mirrored by its mRNA levels, indicating that sucrase activity is regulated at the level of gene expression (74). The carbohydrate-stimulated rise of BBM sucrase activity following sucrose feeding involves an increase of sucrase-isomaltase gene expression at the transcriptional levels (75). Intestinal galactosyltransferase activities are also under developmental regulation in the rat small intestine (76).

While the BBM activity of sucrase is correlated with the carbohydrate content of the diet, it is not affected by age throughout the adult lifespan of the rat (77). The acute increase in sucrasespecific activity following refeeding is similar in adult and aged rats, suggesting that the carbohydrate-digesting capacity of the small intestine 
enterocyte is not impaired during the ageing process. Indeed, the jejunal BBM activities of sucrase and isomaltase increase with ageing in the rat (78). The increased level of intestinal hydroxylase activity may be the consequence of prolonged cellular maturation along the villi in the proximal intestine, and of adaptation to increased concentrations of intraluminal substrates in the distal intestine.

Crypt cell production rate: Under steady-state conditions the intestinal crypt cell production rate parallels the rate of villus epithelial cell loss. Starvation reduces and refeeding increases the crypt cell production rate. Compared with young animals, senescent rats show increased basal DNA synthetic activity. Starvation results in smaller decreases in DNA labelling of crypt cells in senescent rats and abrupt broadening of the proliferative zone, without concomitant increases in the number of villus cells during refeeding. These findings suggest that the tight modulation of cell production is disturbed during starvation and refeeding in the senescent rat. Ageing does not impair the abilities of rats to maintain normal villus cell numbers. It may, however, be associated with altered control of cell replication and proliferation (79).

Mechanisms: The topic of "neuromuscular function and dysfunction of the gastrointestinal tract in aging" has been reviewed (80). What might be the mechanism(s) for age-associated alterations in intestinal function? The jejunal BBM is a relatively fluid structure at birth which becomes progressively more rigid with age. Lipid permeability is greatest during the suckling period of rats but decreases thereafter when animals are placed on chow (81). Alterations in lipid permeability are correlated with maturation of the BBM, both in terms of its lipid fluidity and chemical composition: the static component of BBM fluidity does not change from the suckling to the weaning period, but decreased membrane lipid permeability does correlate with decreasing lipid fluidity, as assessed by probes sensitive to the dynamic component of BBM lipid fluidity within the superficial regions of the bilayer (Figure 3). Small intestinal BLM lipid composition and fluidity also undergoes ontogeny during the weaning period (82). Absorption: Does age affect intestinal absorption? Yes; for example, age-related changes in sodium-dependent glucose transport have been described in rat small intestine (83). Stalnikowicz and Stessman (84) have conducted clinical studies in 43 patients ranging in age from 65 to 96 years. Judged by the normal D-xylose tests in the absence of steatorrhea, they suggested that impairment of intestinal absorption in a geriatric centre was uncommon. However, glucose absorption into BBM vesicles obtained from human small intestine demonstrated that the expected sodium-dependent 'overshoot' phenomenon disappeared in the oldest subjects (85). Age-related declines in intestinal calcium absorption have been suggested in humans. In ageing rats, in vitro calcium transport actually increases in senescence compared to adult animals (86), with maintenance of the $1,25-(\mathrm{OH})_{2} \mathrm{D}_{3}$-stimulated calcium flux being similar in six- and 26 month-old animals. The issue remains controversial since other workers (87) have demonstrated a decline in the maximum uptake capacity of calcium in 24- versus six-month-old rats (concurrent with the decline in serum 1,25 dihydroxy D levels). However, the calcium uptake response in cells isolated from senescent rats was only slightly less than that in cells from adult animals.

Adaptation: The capacity for bowel mucosal growth and adaptation after enterectomy is preserved into old age, but old and not young animals completed their bowel adaptive hyperplasia more rapidly and continued to lose weight (88).

Colonization: The ability to colonize the small intestine is an important virulence attribute of enterotoxigenic $E$ coli. Pili are proteinaceous, filamentous appendages of the bacterial surface that promote the adherence of enterotoxigenic $E$ coli to the epithelium of the small intestine, thereby facilitating intestinal colonization and causing diarrhea. Pilus-specific receptors must be available on intestinal epithelium for pilus-mediated adherence. In contrast to younger animals, older pigs are nor colonized by enterotoxigenic $E$ coll (89), possibly due to release of receptors into the intestinal lumen where they facilitate bacterial clearance rather than adherence.

\section{MOTILITY}

The enteric nervous system has been reviewed $(16,17)$. Theoretical models of intestinal motility, including relaxa. tion oscillator equations, have been considered (90).

Ileal brake: Infusion of lipid emulsion into the human ileum delays transit of both a solid meal from mouth to cecun and a liquid meal from mouth to ileum This has been termed the ileal brake. Delay in small bowel transit during ileal infusion of lipid can be explained by reductions in the rate and degree of propagation of jejunal contractions The mechanism varies according to the type of meal (91). While long and medium chain fatty acids infused int the ileum exert an inhibitory effect on jejunal motility, when infused directl into the jejunum, these partiall digested triglycerides accelerate transit increase jejunal flow and alter the pat tern of jejunal contractions (92). The infusion of the bile acids glycochenodeoxycholic acid and glycocholic aci into the intestine of healthy subject may influence small gut motility (93). For example, short chain fatty acid stimulate human ileal motility. This response is not affected by naloxone or indomethacin (94), and may be as sociated with a motor response to colo ileal reflux.

Migrating myoelectric complexes: Th migrating myoelectric complex is cyclically occurring phenomenon that begins in the stomach and duodenum and propagates to the ileum. Morphine initiates these complexes in the small intestine of fasted humans, and it has been suggested that an endogenous opioid may be involved in initiating endogenously occurring complexes. In dogs, endogenous opioids and opioid receptors may play a role in control of initiation of migrating myoelectric complexes. Pretreatment with 
naloxone before the administration of motilin does not block the initiation of such complexes by motilin, suggesting that motilin and exogenous opioids act via different mechanisms to initiate migrating myoelectric complexes (95). Clonidine and cholecystokinin: The alpha-2 adrenergic agonist clonidine affects intestinal motor function by interactions within the brain and direct interactions at the level of the intestine (96). Orocecal transit time, determined by the lactulose breath $\mathrm{H}_{2}$ method, was increased an average of $70 \%$ in six normal healthy volunteers. This marked effect of clonidine on small bowel motility may explain, at least in part, clonidine's antidiarrheal properties (34).

Cholecystokinin does not appear to play a major role in motility patterns in fasted dogs. It may be involved by itself or by release of pancreatic polypeptide in the induction of the fed motility pattern and postprandial stimulation of the exocrine pancreas (97).

\section{BLOODFLOW}

The splanchnic organs receive about $25 \%$ of the cardiac output by way of the celiac and superior and inferior mesenteric arteries. Bloodflow through the superior mesenteric artery increases postprandially and remains elevated as long as chyme is present in the intestine. The hemodynamic change after a meal probably results from the complex interplay of tissue metabolism, neurohumoral factors, vasoactive substances, myogenic factors and general hemodynamics. In dogs, the responses of superior mesenteric and celiac arterial bloodflow to food differ. The celiac artery's response to pharmacological blocking agents in conscious dogs suggests that its response to food is mediated by a nonadrenergic noncholinergic vagal reflex (98). Extrinsic nerves probably play little part in the postprandial increase of superior mesenteric arterial flow. Compared with the muscularis, the intestinal mucosa possesses more potent local control mechanisms that oppose neurogenic vasoconstriction arising from sympathetic stimulation (99).

Postprandial intestinal bloodflow has been determined using duplex ultrasound measurements in healthy human volunteers. There were no significant changes in any of the bloodflow parameters derived from the celiac or femoral arteries after test meal ingestion (100). In contrast, maximal changes in all superior mesenteric artery parameters were noted after each of the test meals.

In humans, re-establishment of bloodflow to a previously ischemic intestine leads to vascular collapse, possibly due to the liberation of vasoactive agents including vasoactive intestinal polypeptide (101) and gastric inhibitory polypeptide (glucose-dependent insulinotropic polypeptide) which increases superior mesenteric but not celiac arterial flow (102). Oxygen free radicals are probably generated during the post ischemic reperfusion period; superoxide dismutase and catalase ameliorate platelet activating factor-induced ischemia, suggesting that most of the intestinal damage after platelet activating factor injection is due to the release of oxygen radicals (103). Allopurinol ameliorates small bowel lesions by acting as a xanthine oxidase inhibitor.

\section{DIABETES MELLITUS}

The intestinal absorprion of nutrients is increased in animals with streptozotocin-induced diabetes mellitus. This occurs as a result of an increased maximal transport rate of the respective carriers. As well, glucose transporters are recruited from the villus tips to extend towards the base of the intestinal crypts (104). Intestinal uptake of glutamine is also increased in diabetes mellitus. This is reversible upon treatment with insulin and is mediated through an increase in the number and/or activity of glutamine carriers (105).

Fibre: Diets containing soluble fibres reduce the postprandial rise in blood glucose and insulin. This effect may be due to slowing of gastric emptying (related to viscosity developed by soluble fibres), or to the ability of soluble fibre to limit diffusion of enzymes and digested sugars across the unstirred water layer, with resultant retarded as- similation. The effect of fibre is closely related to its viscosity in the presence of diet ingredients (106).

Exocrine pancreatic insufficiency is observed in some diabetics with peripheral neuropathy and diarrhea. This may be due to impairment of exocrine pancreatic secretion (107).

Adrenergic nerves: There is degeneration of adrenergic nerves with changes in the cholinergic and serotonergic innervation of the ileal myenteric plexus in rats eight weeks after streptozotocin induction of diabetes mellitus. This is associated with increased vasoactive intestinal peptide-like immunoreactivity (with no change in substance P-like immunoreactivity). Calcitonin generelated peptide-like immunoreactive nerve fibres in the ileal myenteric plexus are decreased eight weeks after induction of diabetes. Examination of the proximal colon in rats after induction of diabetes with streptozotocin demonstrated decreases in tissue content and density of nerve fibre for noradrenaline, vasoactive intestinal peptide and 5 -hydroxytryptamine by 16 weeks. There was no change in tissue content or density of nerve fibres for substance $P$. This suggests that there is a change in balance of integrated nervous control of the gut in streptozotocin-induced diabetes which may have profound implications on gut function in the diabetic rat with possible parallels in diabetic humans (108).

Glucagon: It is possible that the delayed stomach-to-cecum transit time in diabetic rats is due to associated hyperglucagonemia (109). Hyperglucagonemia may also play a role in diabetes-induced hyperemia in the stomach and jejunum. It does not seem to play a role in the hyperemia seen in the ileum or colon (110). The diminished spontaneous vasoactive intestinal peptide release from intestinal myenteric plexuses in diabetes mellitus is eradicated by insulin treatment (111).

Cholesterol: There is increased small intestinal cholesterol synthesis in diabetic rats which is improved with insulin. Cholesterol synthesized in the small intestine may be transported to the bloodstream, excreted in the feces 
or used in the enterocyte for formation of cellular membranes. In diabetes mellitus, the transport of cholesterol from lymphatics to bloodstream is markedly increased in the chylomicron lipoprotein fraction. Clearance of chylomicrons from the circulation is normal in diabetes mellitus. Thus, the intestinally derived cholesterol is rapidly delivered to the liver. The characteristic increase in small intestinal cholesterol synthesis seen in diabetes mellitus is prevented by total gastrectomy (112). It has been speculated that the stomach produces a substance that increases small intestinal cholesterol synthesis in diabetic animals. Total gastrectomy removes this stimulatory substance.

Diet: Low fat, high carbohydrate diets are recommended for patients with noninsulin-dependent diabetes mellitus in an effort to reduce the risk of coronary artery disease. Yet, short term studies have shown that these diets can lead to changes in carbohydrate and lipid metabolism which are associated with increased risk of coronary artery disease. When these diets are fed to patients for six weeks in a crossover experimental design, plasma glucose and insulin concentrations are elevated; fasting plasma total and very low density lipoprotein (VLDL) triglyceride concentrations are increased; and both low density lipoprotein (LDL) and high density lipoprotein (HDL) cholesterol concentrations are decreased (113). These authors suggested that "the routine recommendation of lowfat high-carbohydrate diets for patients with NIDDM Inoninsulin-dependent diabetes mellitus] should be reconsidered." When dietary saturated fat is replaced with complex carbohydrate in an isocaloric diet in obese Pima Indian noninsulin-dependent diabetic subjects, there is decreased LDL cholesterol but unchanged HDL cholesterol, glucose and body weight (114). These findings are surprising and indicate the importance of further studies in this area.

\section{ETHANOL}

Ethanol, in concentrations found in the human duodenojejunal lumen after moderate drinking, causes changes in the microvasculature of the jejunum. These include increased bloodflow, capillary stasis, microvascular permeability and intestinal plasma protein loss. Acute administration of ethanol to rabbits increases histamine release by the jejunum, and the ethanol-induced plasma protein loss is partially attenuated with $\mathrm{H}_{1}$ and $\mathrm{H}_{2}$ receptor antagonists (115). This therapeutic potential needs to be explored.

The primary cause of ethanol-induced epithelial damage may be related to contraction of the villus core and compression of lymphatics (116). In humans, inhibition of forward progressing and propulsion waves has been described in response to acute ethanol ingestion. This may be due to decreased synthesis of the cytoplasmic protein fraction, including the smooth muscle contractile apparatus (117). Thus, it is possible that functional disturbances in ethanol-exposed gut may arise in part from changes in smooth muscle protein turnover with decreased amounts of contractile apparatus.

The characteristics of the fetal alcohol syndrome in humans include physical, physiological and behavioral abnormalities. These result in elevated mortality rates in the offspring of alcoholic mothers. Ethanol ingestion produces a wide range of gastrointestinal effects in adult mammals. Rat pups from ethanol-treated mothers show decreases in intestinal length and thickness, low total lactase activity and low somatostatin intestinal content (118). Gastroenteropathy may therefore be part of the fetal alcohol syndrome.

\section{RADIATION}

Abdominal irradiation has both acute and chronic effects on a wide range of gastrointestinal functions (119). There is increasing incidence of chronic radiation injury to the bowel requiring surgery. Radiation injury, in addition to necessitating small bowel resection, contributes to malabsorption and diarrhea in patients with ileal resection for radiation sequelae (120). During the first $24 \mathrm{~h}$ following abdominal irradiation, there is an acute inflammatory response characterized by an accumulation of plasma, increased tissue red blood cell volume, and increased mucosal neutrophils. This response is particularly marked in the pericryptal and deep mucosal regions of the small intestine and colon (121), and contrasts with the chronic trans. mural inflammation, fibrotic change and vasculitis seen with chronic or sub. acute radiation enteropathy. Irradiation, alone or associated with graft versus host reaction, profoundly depletes rat mucosal mast cells and reduces jejunal and serum levels of rat mast cell protease (122). The acute gastrointestinal side effects of radiation therapy are likely due to changes in mucosal structure and epithelial transport. Some of the side effects of radiation such as diarrhea, abdominal cramping and vomiting may also be related to an increased incidence of giant migrating contractions and retrograde giant contractions (123).

The stem cell population of rodent intestinal epithelium is contained in the crypt. There appear to be two radiobiologically distinct populations, a cryptogenic stem cell population capable of regenerating the crypt after radiation injury, and a more radiosensitive proliferative cell population which undergoes more rapid cell division. The differing radiosensitivities of sub. populations are due to varying degrees of differentiation attained by cells in the subpopulations which, in the intes. tinal epithelium, are related to their positions in the crypt. Treatment of in. testinal epithelial cells with a differen. tiating agent such as N,N-dimethyl. formamide may alter the mixture of subpopulations, decrease the cryptogenic stem cell population and increase the concomitant progenitor cell subpopulation so that induction of differentiation may decrease the sensitive and increase the resistant component in the crypt cells (124).

Prospects for management of gastrointestinal injury associated with the acute radiation syndrome have heen reviewed (125). An alkaline luminal environment provides partia protection from acute radiation injur to the small bowel mucosa (126). The thiol derivative WR-2721 increase survival in rodents exposed to letha 
doses of radiation. This protective effect is potentiated by prostaglandin analogues such as nocloprost (127). Double-blind histological evaluation of colons from irradiated rats treated with intercolonic WR-2721 has demonstrated a radioprotective effect with a dose-modifying factor of 1.8 compared to controls (128). 5-Aminosalicylic acid scavenges reactive oxygen free radicals; pretreatment with 5-Aminosalicylic acid appears to protect against radiation injury in cultured human colon cancer cells. Unfortunately, post irradiation treatment with 5 -aminosalicylic acid does not prevent the development of radiation damage (129).

\section{REFERENCES}

1. Fingerote R, Thomson ABR. Small bowel review. In: Gitnick G, ed. Current Gastroenterology Chicago: Year Book Medical Publishers. (In press)

2. Field M, Rao MC, Chang EB. Intestinal electrolyte transport and diarrheal disease. N Engl ] Med 1989;321:800-6.

3. Sellin JH, Oyarzabal H, Cragoe EJ, Potter GD. Phenamil inhibits electrogenic sodium absorption in rabbit ileum. Gastroenterology 1989;96:997-1003.

4. Knickelbein RG, Aronson PS, Dobbins JW. Membrane distribution of sodium-hydrogen and chloride-bicarbonate exchangers in crypt and villus cell membranes from rabbit ileum.

JClin Invest 1988;82:2158-63.

5. Orsenigo MN, Tosco M, Esposito G, Faelli A. Ouabain-insensitive $\mathrm{Na}$-ATPase activity in the basolateral membrane from rat jejunum. Int J Biochem 1988;20:1411-5.

6. Charney AN, Ingrassia PM, Thaler SM, Keane MG. Effect of systemic $\mathrm{pH}$ on models of altered ileal transport in the rat. Gastroenterology 1989;96:331-8.

7. Cohen MB, Thompson MR, Giannella RA. Differences in jejunal and ileal response to $E$ coli enterotoxin: Possible mechanisms. Am J Physiol 1989:257:G1 18-23.

8. Farack UM, Gerzer R, Keravis TM, Loeschke K. Discrepancy between effects of cholera toxin on net fluid movement and cAMP levels in rat jejunum, ileum and colon. Dig Dis Sci 1988;33:1153-8.

9. Baubler E, Kollar G, Saria A, Bukhave K, Rask-Madsen I. Involvement of 5-hydroxytryptamine, prostaglandin
Damage to the microvasculature may also play a key role in the onset of late radiation damage in the rectum (130). Bleeding, stricture, perforation or fistulas are common late complications of radiation enteritis. In patients with radiation enteritis presenting with perforation or fistula, life expectancy is poor compared to patients presenting with bleeding or stricture (131). Colonic or anorectal cancer may occur following pelvic irradiation for other malignant or benign lesions (132). In a series of 76 patients, malignancy occurred a mean of 15.2 years following irradiation, with a peak frequency between five and 10 years post irradiation.

$\mathrm{E}_{2}$, and cyclic adenosine

monophosphate in cholera

toxin-induced fluid secretion in the

small intestine of the rat in vivo.

Gastroenterology 1989;96:368-76.

10. Munck LK, Mertz-Nielsen A, Westh

$\mathrm{H}$, Bukhave K, Baubler E, Rask

Madsen J. Prostaglandin $E_{2}$ is a

mediator of 5-hydroxytryptamine

induced water and electrolyte secretion

in the human jejunum. Gut

1988;29:1337-41.

11. Gaginella TS, Kachur JF. Kinins as mediators of intestinal secretion. Am J Physiol 1989;256:G1-15

12. Sharma JN. The kinin system and prostaglandins in the intestine. Pharmacol Toxicol 1988;63:310-6.

13. Homaidan FR, Donowitz M, Wetland GA, Sharp GWG. Two calcium channels in basolateral membranes of rabbit ileal epithelial cells. Am J Physiol 1989;257:G86-93.

14. Fedorak RN, Kotake A, Douglas F. Chang EB. Inhibition of cholera-toxin-stimulated intestinal secretion by CGS 9343B in rats: A specific calmodulin inhibitor. J Pediatr Gastroenterol Nutr 1989;8:252-8.

15. Stoll R, Ruppin H, Domschke W. Calmodulin-mediated effects of loperamide on chloride transport by brush border membrane vesicles from human ileum. Gastroenterology 1988;95:69-76

16. Lundgren $\mathrm{O}$, Svanvik J, Jivegard L. Enteric nervous system. I. Physiology and pathophysiology of the intestinal tract. Dig Dis Sci 1989;34:264-83.

17. Jodal M, Eklund S, Sjovall H. Enteric nerves and function of intestinal mucosa. Physiological and pathophysiological aspects. Dig Dis Sci 1988:6:203-15

18. Brown DR, Chandan R, Quito FL,
This suggests that surveillance of the colon and anorectal region in pelvic-irradiated patients starting five years after irradiation may be indicated. A case report of synchronous large and small bowel cancer developing after pelvic irradiation supports the belief that there is a causal relationship between therapeutic radiation and subsequent bowel malignancy (133). Post radiotherapy malabsorption may be due to intestinal lymphangiectasia (134). Colostomy carries the lowest risk of mortality for the surgical treatment of intestinal radiation injury compared with resection and bypass procedures (135).

Seybold VS. Receptor regulation of ion transport in the intestinal epithelium. Life Sci 1988;43:2193-201.

19. Goyal RK. Identification, localization and classification of muscarinic receptor subtypes in the gut. Life Sci 1988;43:2209-20.

20. Cooke HJ. Role of the 'little brain' in the gut in water and electrolyte homeostasis. FASEB J 1989;3:127-38.

21. Hubel KA, Renquist KS, Varley G. Noradrenergic influence on epithelial responses of rabbit ileum to secretagogues. Am J Physiol 1989;256:G919-24.

22. Carey HV, Cooke JG.

Neuromodulation of intestinal transport in the suckling mouse. Am J Physiol 1989;256:R481-6

23. Ferri G-L, Watkinson A, Dockray GJ. Proenkephalin A-derived peptides in the human gut. Gastroenterology 1988;95:1011-7.

24. Galligan JJ, Surprenant A, Toninin M, North RA. Differential localization of 5- $\mathrm{HT}_{1}$ receptors on myenteric and submucosal neurons. Am J Physiol 1988;255:G603-11.

25. Spokes RA, Yiangou Y, Chrysanthou B], Bowles MPS, Bloom SR. Effects of prepro-vasoactive intestinal polypeptide-derived peptides on net fluid flux in small intestine of anesthetized rats. Gastroenterology 1989;96:327-30.

26. Vidal H, Riou J-P. Alpha-2 adrenergic stimulation counteracts the metabolic effects of vasoactive intestinal peptide in isolated rat enterocytes. Endocrinology 1989;124:3117-21.

27. Chandan R, Newell SM, Brown DR. Actions of gastrin-releasing peptide and related mammalian and amphibian peptides on ion transport in the porcine proximal jejunum. Regul Pept 
1988;23:1-14.

28. Rolston RK, Ghatei MA, Mulderry PK, Bloom SR. Intravenous calcitonin gene-related peptide stimulates net water secretion in rat colon in vivo. Dig Dis Sci 1989;34:612-6.

29. Vollmar AM, Friedrich A, Sinowatz F, Schulz R. Presence of atrial natriuretic peptide-like material in guinea pig intestine. Peptides 1988;9:965-71.

30. Bianchi C, Thibault G, DeLean A, Genest J, Catin M. Atrial natriuretic factor binding sites in the jejunum. Am J Physiol 1989;256:G436-41.

31. Roberts WG, Fedorak RN, Chang EB. In vitro effects of the long-acting somatostatin analogue SMS 201-995 on electrolyte transport by rabbit ileum. Gastroenterology 1988;94:1343-50.

32. Rodrigues CA, Lennard-Jones JE, Thompson DG, Forthing MJG. The effects of octreotide, soy polysaccharide, codeine and loperamide on nutrient, fluid and electrolyte absorption in the short-bowel syndrome. Aliment Pharmacol Therap 1989;3:159-69.

33. Rabbani GH, Butler T, Patte D, Abud RL. Clinical trial of clonidine hydrochloride as an antisecretory agent in cholera. Gastroenterology 1989;97:321-5.

34. Rubinoff MJ, Piccione PR, Holt PR. Clonidine prolongs human small intestine transit time: Use of the lactulose-breath hydrogen test. Am J Gastroenterol 1989;84:372-4.

35. LaPook J, Fedorak RN. Oral rehydration therapy: WHO at 40, ORT at 30. Can J Gastroenterol 1989;3:7-14.

36. Patra FC, Mahalanabis D, Jalan KN. Bicarbonate enhances sodium absorption from glucose and glycine rehydration solutions. Acta Paediatr Scand 1989;78:379-83.

37. Rolston DDK, Kelly MJ, Borodo MM, Dawson AM, Farthing MJG. Effect of bicarbonate, acetate and citrate on water and sodium movement in normal and cholera toxin-treated rat small intestine. Scand J Gastroenterol 1989;24:1-8.

38. Islam MR, Ahmed SM. Oral rehydration solution without bicarbonate. Arch Dis Child 1989;59:1072-5.

39. Reiser SB, Weiser HF, Schusdziarra V, Siewert JR. Effect of pacing on small intestinal motor activity and hormonal response in dogs. Dig Dis Sci 1989;34:579-84.

40. Wittmann T, Crenner F, Koenig M, Grenier JF. Adaptive changes in postprandial motility after intestinal resection and bypass.

Electromyographic study in rats. Dig Dis Sci 1988;33:1370-6.

41. Nagy LE, Pittler A, Kretchmer N.
Development of glutaminase along the villus-crypt axis in the jejunum of rat. J Pediatr Gastroenterol Nutr 1988;7:907-13.

42. Grant JP, Snyder PJ. Use of L-glutamine in total parenteral nutrition.

J Surg Res 1988;44:506-13.

43. Koruda MJ, Rolandelli RH, Settle RG, Zimmaro DM, Rombeau JL. Effect of parenteral nutrition supplemented with short-chain fatty acids on adaptation to massive small bowel resection. Gastroenterology 1988;95:715-20.

44. Moore R, Carlson S, Madara JL. Rapid barrier restitution in an in vitro model of intestinal epithelial injury. Lab Invest 1989;60:237-44.

45. Waller DA, Thomas NW, Self T]. Epithelial restitution in the large intestine of the rat following insult with bile salts. Virchows Arch [A] 1988;414:77-81.

46. Hollander D, Koyama S, Dadufalza V, et al. Polyethylene glycol 900 permeability of rat intestinal and colonic segments in vivo and brush border membrane vesicles in vitro. I Lab Clin Med 1989;113:505-15.

47. Vazquez CM, Molina MT, Ilundain A. Distal small bowel resection increases mucosal permeability in the large intestine. Digestion 1988;40:168-72.

48. Madara JL. Loosening tight junctions. Lessons from the intestine. J Clin Invest 1989;83:1089-94.

49. Madara JL, Stafford J. Interferon- $\tau$ directly affects barrier function of cultured intestinal epithelial monolayers. J Clin Invest 1989;83:724-7.

50. Goodlad RA. Gastrointestinal epithelial cell proliferation. Dig Dis 1989;7:169-77.

51. Gordon JI. Intestinal epithelial differentiation: New insights from chimeric and transgenic mice. J Cell Biol 1989;108:1187-94.

52. Johnson LR, Tseng C-C, Wang $P$, Tipnis JR, Haddox MK. Mucosal ornithine decarboxylase in the small intestine: Localization and stimulation. Am J Physiol 1989;256:G624-30.

53. Stallmach A, Hahn U, Merker JH, Hahn EG, Riecken EO. Differentiation of rat intestinal epithelial cells is induced by organotypic mesenchymal cells in vitro. Gut 1989;30:959-70.

54. Kumagai J, Jain R, Johnson LR. Characteristics of spermidine uptake by isolated rat enterocytes. Am J Physiol 1989;256:C905-10.

55. Ginty DD, Osborne DL, Seidel ER. Putrescine stimulates DNA synthesis in intestinal epithelial cells. Am J Physiol 1989;257:G145-50.

56. Ginty DD, Seidel ER.
Polyamine-dependent growth and calmodulin-regulated induction of ornithine decarboxylase. Am J Physiol 1989;256:G342-8.

57. Mennigen R, Bieganski T, Elbers A, Kusche J. The histamine-diamine oxidase system and mucosal proliferation under the influence of aminoguanidine and seventy percent resection of the rat small intestine. Agents Actions 1989;27:221-3.

58. Becciolini A, Porciani S, Lanini A, Attanasio M. Polyamines in the small intestine of rats after whole-body irradiation. Int J Radiat Biol 1989;56:67-73.

59. Fitzpatrick LR, Gaginella TS, Haddox MK, Johnson LR.

Prostaglandin-mediated trophic effects on the rat duodenum: The role of polyamines. Proc Soc Exp Biol Med 1988;189:201-5.

60. Crissinger KD, Grisham MB, Granger DN. Developmental biology of oxidant-producing enzymes and antioxidants in the piglet intestine. Pediatr Res 1989;25:612-6.

61. Schaudies RP, Grimes J, Davis D, Rao RK, Koldovsky O. EGF content in the gastrointestinal tract of rats: Effect of age and fasting/feeding. Am J Physiol 1989;256:G856-61.

62. Menard D, Arsenault P, Pothier P. Biologic effects of epidermal growth factor in human fetal jejunum. Gastroenterology 1988;94:656-63.

63. Weaver LT, Freiberg E, Israel EJ, Walker WA. Epidermal growth factor in human amniotic fluid.

Gastroenterology 1989;95:1436. (Lett)

64. DiJoseph JF, Wells CL. Effect of epidermal growth factor on non-steroidal anti-inflammatory drug-induced intestinal damage. Agents Actions 1989;27:294-6.

65. Puccio F, Lehy T. Bombesin ingestion stimulates epithelial digestive cell proliferation in suckling rats. Am ] Physiol 1989;256:G328-34.

66. Goodlad RA, Gregory H, Wright NA. Is polyamine synthesis involved in the proliferative response of the intestinal epithelium to urogastrone-epidermal growth factor? Clin Sci 1989;76:595-8

67. Drumm B, Cutz E, Tomkins KB, Cook D, Hamilton JR, Sherman P.

Urogastrone/epidermal growth factor in treatment of congenital microvillous atrophy. Lancet 1988;i:111-2.

68. Koyama S-Y, Podolsky DK. Differential expression of transforming growth factors $\alpha$ and $\beta$ in rat intestinal epithelial cells. J Clin Invest 1989;83:1768-73.

69. Craven PA, DeRubert is FR. Role of activation of protein kinase $\mathrm{C}$ in the stimulation of colonic epithelial proliferation by unsaturated fatty acids. 
Gastroenterology 1988;95:676-85.

70. Alarcon P, Lin CH, Lebenthal E, Lee PC. Interaction of malnutrition and difluoromethylornithine-induced intestinal mucosal damage: Degree of severity and subsequent recovery. Digestion 1988;41:68-77.

71. Morrill JS, Kwong LK, Sunshine P, Briggs GM, Castillo RO, Tsuboi KK. Dietary $\mathrm{CHO}$ and stimulation of carbohydrases along villus column of fasted rat jejunum. Am J Physiol 1989;256:G158-65.

72. Weber FL, Fresard KM, Veach GL. Stimulation of jejunal mucosal protein synthesis by luminal glucose. Effects with luminal and vascular leucine in fed and fasted rats. Gastroenterology 1989;96:935-7

73. Yeh K-Y, Yeh M, Holt PR. Differential effects of thyroxine and cortisone on jejunal sucrase expression in suckling rats. Am J Physiol 1989;256:G604-12.

74. Henning SJ, Leeper LL. Expression of the sucrase-isomaltase gene during rat development. Gastroenterology 1989;96:A205. (Abst)

75. Hugot J-P, Perret C, Broyart J-P, Mantel N, Semenza G. Regulation of sucrase-isomaltase messenger RNA concentration in rat small intestine by sucrose feeding. Gastroenterology 1989;96:A221. (Abst)

76. Ozaki CK, Chu S-W, Walker WA. Developmental changes in galactosyltransferase activity in the rat small intestine. Biochim Biophys Acta 1989;991:243-7.

77. Rosamond WD, Savaiano DA. Maintenance of sucrase activity in rat small intestine. Influence of diet and age. Dig Dis Sci 1988;33:1397-402.

78. Raul F, Gosse F, Doffoel M, Darmenton P, Wessely JY. Age related increase of brush border enzyme activities along the small intestine. Gut 1988;29:1557-63.

79. Holt PR, Yeh K-Y, Kotler DP. Altered controls of proliferation in proximal small intestine of the senescent rat. Proc Natl Acad Sci US A 1988;85:2771-5.

80. Szurszewski JH, Holt PR, Schuster M. Proceedings of a workshop entitled Neuromuscular function and dysfunction of the gastrointestinal tract in aging.' Dig Dis Sci 1989;34:1135-46.

81. Meddings JB, Theisen S. Development of rat jejunum: Lipid permeability, physical properties, and chemical composition. Am J Physiol 1989;256:G931-40.

82. Schwarz SM, Bostwick HE, Danziger MD, Newman LJ, Medow MS. Ontogeny of basolateral membrane lipid composition and fluidity in small intestine. Am J Physiol 1989;257:G138-44.
83. Freeman HJ, Quamme GA.

Age-related changes in

sodium-dependent glucose transport in rat small intestine. Am J Physiol 1986;251:G208-17.

84. Stalnikowicz R, Waksman R, Stessman J. Does age affect gut absorption? J Clin Gastroenterol 1988;10:701-2. (Lett)

85. Vincenzini MT, Iantomasi $T$, Stio $M$, et al. Glucose transport during ageing by human intestinal brush-border membrane vesicles. Mech Ageing Dev 1989;48:33-41.

86. Mooradian AD, Song MK. Age-related alterations in duodenal calcium transport rate in rats. Mech Ageing Dev 1989;47:221-7.

87. Liang CT, Barnes J, Takamato S, Sacktor B. Effect of age on calcium uptake in isolated duodenum cells: Role of 1,25-dihydroxyvitamin $\mathrm{D}_{2}$. Endocrinology 1989;124:2830-6.

88. Poston GJ, Saydjari R, Lawrence JP. Alexander RW, Townsend CM, Thompson JC. Effect of age on small bowel adaptation and growth after proximal enterectomy. $\mathrm{Br} \mathrm{Soc}$ Gastroenterol 198:A1468.

89. Dean EA, Whipp SC, Moon HW. Age-specific colonization of porcine intestinal epithelium by $987 \mathrm{P}$-piliated enterotoxigenic Escherichia coli. Infect Immun 1989;57:82-7.

90. Publicover NG, Sanders KM. Are relaxation oscillators an appropriate model of gastrointestinal electrical activity? Am J Physiol 1989;256:G265-74.

91. Welch IMcL, Davison PA, Worlding J, Read NW. Effect of ileal infusion of lipid on jejunal motor patterns after a nutrient and nonnutrient meal. Am J Physiol 1988;255:G800-6.

92. Spiller RC, Trotman IF, Adrian TE, Bloom SR, Misiewicz JJ, Silk DBA. Further characterisation of the 'ileal brake' reflex in man - Effect of ileal infusion of partial digests of fat, protein and starch on jejunal motility and release of neurotensin, enteroglucagon, and peptide YY. Gut 1988;29:1042-51.

93. Penagini R, Misiewicz JJ, Frost PG. Effect of jejunal infusion of bile acids on small bowel transit and fasting jejunal motility in man. Gut 1988;29:789. (Abst)

94. Kamath PS, Phillips SF, Zinsmeister AR. Short-chain fatty acids stimulate ileal motility in humans. Gastroenterology 1988;95:1496-502.

95. Telford GL, Condon RE, Szurszewski $\mathrm{JH}$. Opioid receptors and the initiation of migrating myoelectric complexes in dog. Am J Physiol 1989;256:G72-7.

96. Jiang Q, Sheldon RJ, Porreca F. Sites of clonidine action to inhibit gut propulsion in mice: Demonstration of a central component. Gastroenterology 1988;95:1265-71.

97. Thor P, Laskiwicz J, Konturek P, Konturek SJ. Cholecystokinin in the regulation of intestinal motility and pancreatic secretion in dogs. Am J Physiol 1988;255:G498-504

98. Takagi T, Naruse S, Shionoya S. Postprandial celiac and superior mesenteric bloodflows in conscious dogs. Am J Physiol 1988;255:G522-8.

99. Shepherd AP, Riedel GL. Intramural distribution of intestinal bloodflow during sympathetic stimulation. Am J Physiol 1988;255:G1091-H1095.

100. Moneta GL, Taylor DC, Helton WS, Mulholland MW, Strandness DE Jr. Duplex ultrasound measurement of postprandial intestinal bloodflow: Effect of meal composition. Gastroenterology 1988;95:1294-301.

101. Somjen G, Fletcher DR, Shulkes A, Hardy KJ. Effect of vasoactive intestinal polypeptide on systemic and splanchnic haemodynamics: Role in vasodilation following mesenteric ischaemia. Digestion 1988;40:133-43.

102. Kogire M, Inoue K, Sumi S, et al. Effects of synthetic human gastric inhibitory polypeptide on splanchnic circulation in dogs. Gastroenterology 1988;95:1636-40.

103. Cueva JP, Hsueh W. Role of oxygen derived free radicals in platelet activating factor induced bowel necrosis. Gut 1988;29:1207-12.

104. Fedorak RN, Gershon MD, Field M. Induction of intestinal glucose carriers in streptozotocin-treated chronically diabetic rats. Gastroenterology 1989;96:37

105. Van Voorhis K, Said HM, Ghishan FK, Abumrad N. Effect of diabetes mellitus on glutamine (gin) transport across rat intestinal brush border membrane (BBMV). Gastroenterology 1989;96:A526. (Abst)

106. Vachon C, Jones JD, Wood PJ, Savoie L. Concentration effect of soluble dietary fibers on postprandial glucose and insulin in the rat. Can J Physiol Pharmacol 1988;66:801-6.

107. El Newihi H, Dooley CP, Saad C, Staples J, Zeidler A, Valenzuela JE. Impaired exocrine pancreatic function in diabetics with diarrhea and peripheral neuropathy. Dig Dis Sci 1988;33:705. (Abst)

108. Belai A, Lincoln J, Milner P, Burnstock G. Progressive changes in adrenergic, serotonergic, and peptidergic nerves in proximal colon of streptozotocin-diabetic rats. Gastroenterology 1988;95:1234-41.

109. Chesta J, Debnam ES, Srai SKS, Epstein O. Deiayed stomach to cecum transit time in the diabetic rat: Possible 
role of hyperglucagonaemia. $\mathrm{Br} \mathrm{Soc}$ Gastroenterol 198:A1466. (Abst)

110. Yrle LF, Smith JK, Benoit JN, Granger DN, Korthuis RJ. Role of glucagon in intestinal hyperemia associated with early experimental diabetes mellitus. Am J Physiol 1988;255:G542-6.

111. Nowak TV, Weisbruch JP, Fouquet G, Chang TM, Chey WY. Diminished vasoactive intestinal polypeptide (VIP) release from diabetic rodent small intestine: Normalization with insulin treatment. Gastroenterology 1989;96:A368. (Abst)

112. Feingold KR, Zeng Q-H, Soued M, et al. Total gastrectomy and small intestinal cholesterol synthesis in diabetic rats. Diabetes 1989;38:219-24.

113. Coulston AM, Hollenbeck CB, Swislocki ALM, Reaven GM. Persistence of hypertriglyceridemic effect of low-fat high-carbohydrate diets in NIDDM patients. Diahetes Care 1989;12:94-101.

114. Abbott WGH, Boyce VL, Grundy SM, Howard BV. Effects of replacing saturated fat with complex carbohydrate in diets of subjects with NIDDM. Diabetes Care 1989;12:102-7.

115. Dinda PK, Leddin DJ, Beck IT. Histamine is involved in ethanol-induced jejunal microvascular injury in rabbits. Gastroenterology 1988;95:1227-33.

116. Ray M, Dinda PK, Beck IT. Mechanism of ethanol-induced jejunal microvascular and morphologic changes in the dog. Gastroenterology 1989;96:345-54.

117. Preedy VR, Duane P, Peters TJ. Acute ethanol dosage reduces the synthesis of smooth muscle contractile proteins in the small intestine of the rat. Gut 1988;29:1244-8.
118. Lopez-Tejero D, Arilla E, Colas B, Llobera M, Herrera E. Low intestinal lactase activity in offspring from ethanol-treated mothers. Biol Neonate 1989;55:204-13.

119. Yeoh E, Horowitz M, Maddox A, et al. Effects of abdominal irradiation on gastrointestinal function. Gastroenterology 1989;96:A 560. (Abst)

120. Miholic J, Vogelsang H, Schlappack O, Kletter K, Szepesi T, Moeschl P. Small bowel function after surgery for chronic radiation enteritis. Digestion 1989;42:30-8.

121. Buell MG, Harding RK. Proinflammatory effects of local abdominal irradiation on rat gastrointestinal tract. Dig Dis Sci 1989;34:390-9.

122. Cummins AG, Munro GH, Huntley JF, Miller HRP, Ferguson A. Separate effects of radiation and of graft-versus-host reaction on rat mucosal mast cells. Gut 1989;30:355-60

123. Otterson MF, Sarna SK, Moulder JE. Effects of fractionated doses of ionizing radiation on small intestinal motor activity. Gastroenterology 1988;95:1249-57.

124. DeRose C, Claycamp HG. Dimethylformamide-induced changes in the radiation survival of low-and high-passage intestinal epithelial cells (IEC-17) in vitro. Radiat Res 1989;118:269-82.

125. Dubois A, Walker RI. Prospects for management of gastrointestinal injury associated with the acute radiation syndrome. Gastroenterology 1988;95:500-7.

126. Delaney JP, Bonsack M, Kimm E. The role of luminal $\mathrm{pH}$ in acute radiation enteritis. Gastroenterology 1989;96:A116. (Abst)

127. Vigneulle RM, Pekley T, Kitto G, et al. Intestinal radioprotective properties of the prostaglandin $\mathrm{E}_{2}$ analog nocloprost in canines. Gastroenterology 1989;96:A529. (Abst)

128. France $H G$ Jr, Jirtle RL, Mansbach CM II. Intracolonic WR2721 protection of the rat colon from acute radiation injury.

Gastroenterology 1986;91:644-50.

129. Desai TK, Yanamadala U, Bull A, Kim Y, Crissman J, Luk GD

5-aminosalicylic acid (5-ASA) pretreatment protects against radiation injury. Gastroenterology 1989;96:A120. (Abst)

130. Dewit L, Oussoren Y. Vascular injury in the mouse rectum after irradiation and cis-diaminedichloroplatinum (II) Br J Radiol 1987;60:1037-40.

131. Harling $\mathrm{H}$, Balslev I. Long-term prognosis of patients with severe radiation enteritis. Am J Surg 1988;155:517-9.

132. Jao S-W, Beart RW, Reiman HM Gunderson LL, Ilstrup DM. Colon and anorectal cancer after pelvic irradiation. Dis Colon Rectum 1987;30:953-8

133. Gajraj H, Davies DR, Jackson BT. Synchronous small and large bowel cancer developing after pelvic irradiation. Gut 1988;29:126-8.

134. Rao SSC, Dundas S, Holdsworth CD. Intestinal lymphangiectasia secondary to radiotherapy and chemotherapy. Dig Dis Sci 1987;32:939-42.

135. Makela J, Nevasaari K, Kairaluoma MI. Surgical treatment of intestinal radiation injury. J Surg Oncol $1987 ; 36: 93-7$. 


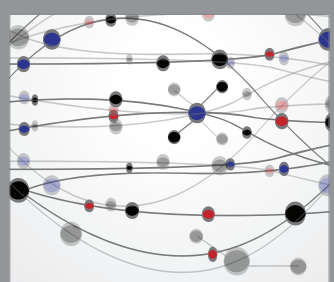

The Scientific World Journal
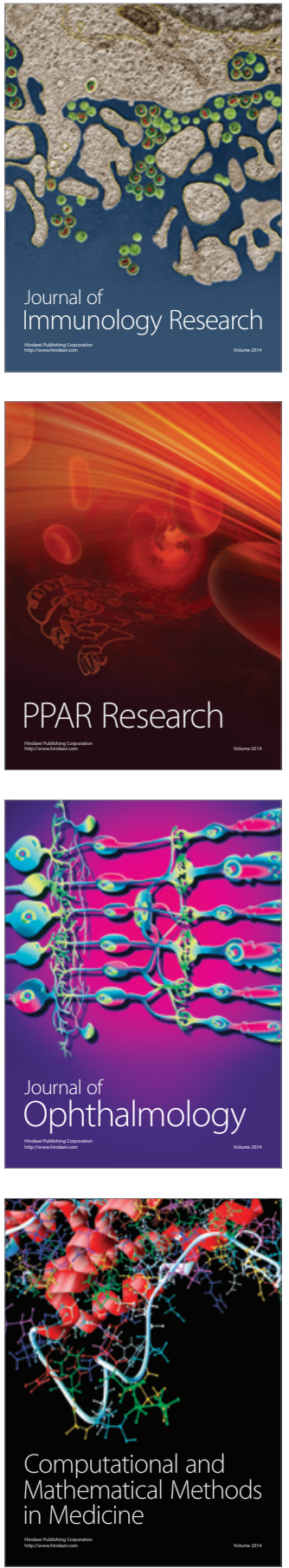

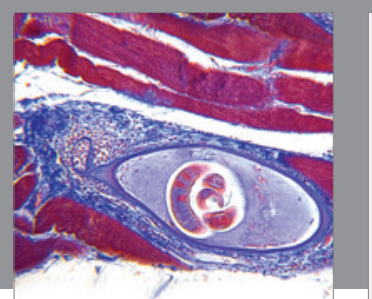

Gastroenterology Research and Practice

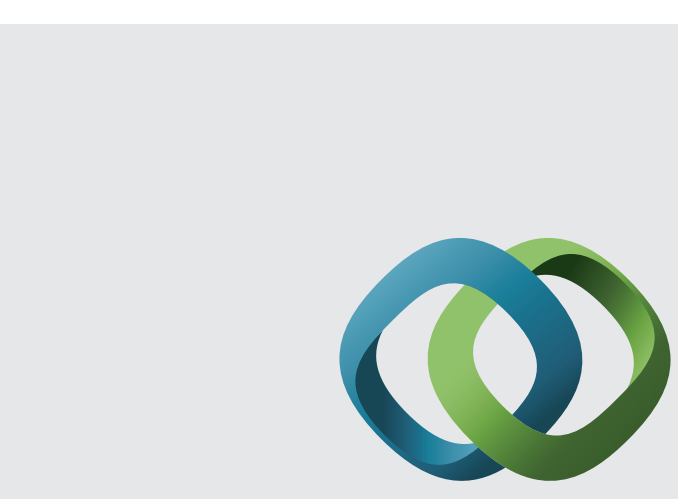

\section{Hindawi}

Submit your manuscripts at

http://www.hindawi.com
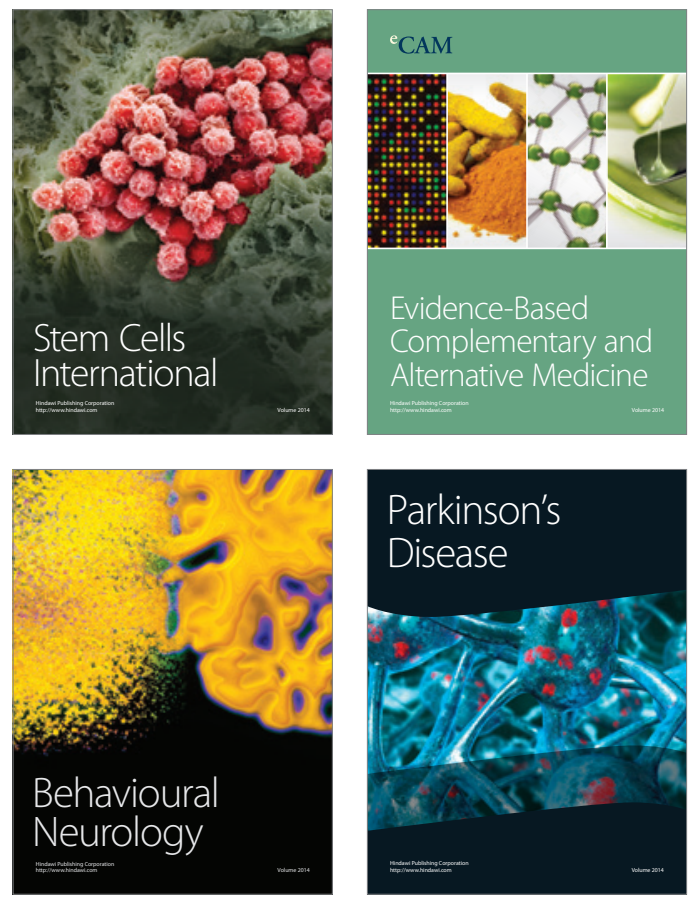
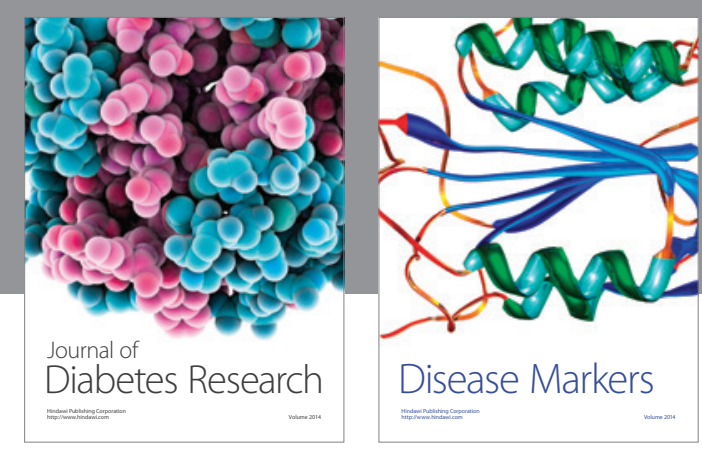

Disease Markers
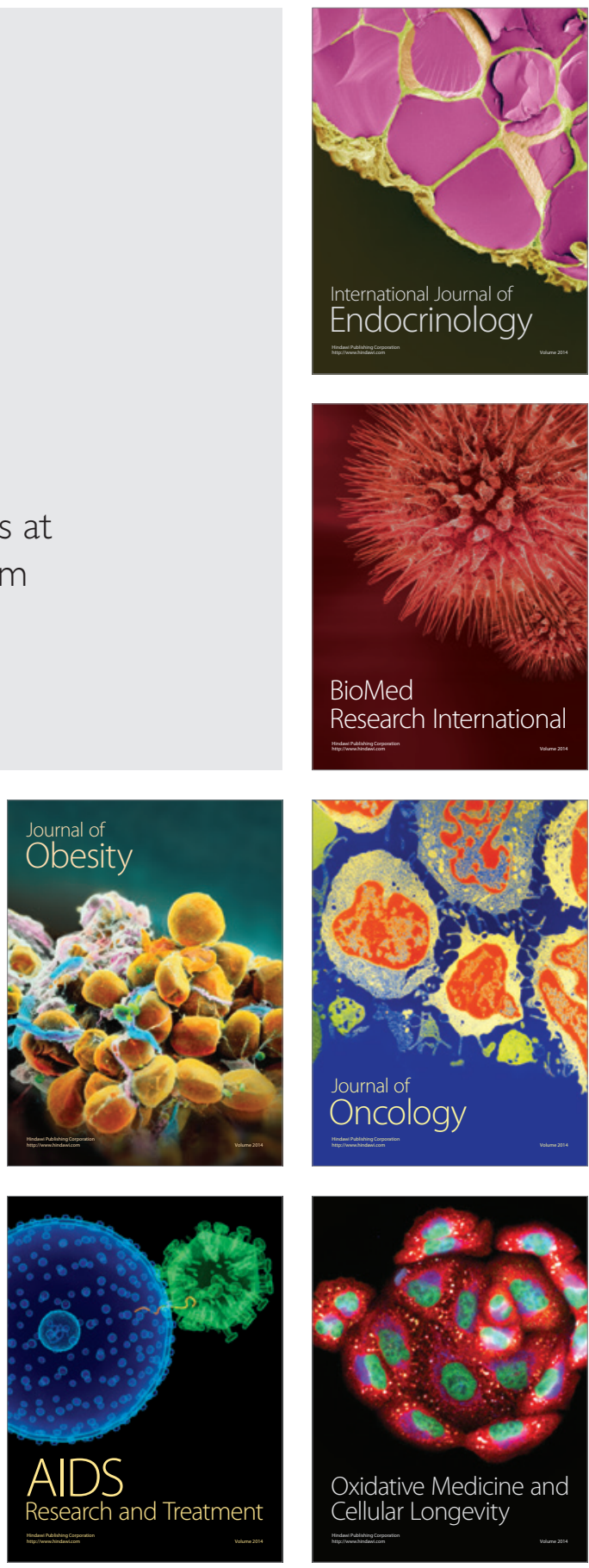